\title{
VALUE CHAIN ANALYSIS AT TUNA PROCESSED AGROINDUSTRY IN PACITAN, EAST JAVA
}

\author{
Irfan Miftahul ${ }^{*}$, Budi Setiawan², Anthon Efani ${ }^{3}$ \\ ${ }^{1}$ Post Garduate Student at Econoimics Agriculture, Brawijaya University, Indonesia \\ ${ }^{2}$ Lecturer at Socio-Economics Agriculture, Brawijaya University, Indonesia \\ ${ }^{3}$ Lecturer at Socio-Econimics Fisheries, Brawijaya University, Indonesia \\ *coresponding author: Irfannfauzi99@gmail.com
}

\begin{abstract}
Indonesia's economy was convener of the sea; however, the poverty of the fishermen is still high enough. The factors of management and utilization of marine fishery resources in order to improve the people's welfare are should be a significant concern. The leading commodities, tuna fish, need to be supported to increase production, processing, distribution system, diversified products. A good marketing and marketing margin distribution should be allocating a fairer on the processed tuna products. The purpose of this research is to analyze the mapping, critical factors that influence, and business value chain improvement strategies processing tuna in Pacitan. Research conducted on agro-industries processing tuna in district of Pacitan, Pacitan Regency, East Java. Sampels used are 4 fishermens, 2 traders, 2 agro-industries, 4 managers, 4 resellers, 4 retailers, and 50 consumers. Data retrieval is performed in February-March 2018. Data are analyzed using the mapping analysis, analysis of the Critical Success Factor (CSF), the analysis of governane, analysis of upgrading. Based on the analysis of the principals involved in agro-industries processing tuna are fishermens, traders, agro-industries, retailers, resellers and consumers. The party receives the smallest profit amounting to $\mathrm{Rp} 4,000$ fishermen $/ \mathrm{kg}$. Critical factors according to agro-industries are the taste, price and quality, while the critical factor according to consumers is the taste, quality, expiration date. Factors that have a high gap are 0.49 stock and 0.55 of innovation and 0.73 of expiration. Upgrading of value chain processed tuna is process improvement by increasing production capacity, increasing the role of Marketing Manager for network marketing with branding in the tourism industry so processed tuna products widely known both national and international.
\end{abstract}

Keywords: tuna processed, value chain analysis, upgrading

http://dx.doi.org/10.21776/ub.agrise.2019.019.1.5

Received 26 September 2018

Accepted 17 January 2019

Available online 2 March 201

\section{INTRODUCTION}

The sea is the driving force of the economy so as to make the archipelago an Honorable position in the trade regulation, economic, geopolitical and security defense. However the wealth of fisheries and marine resources has yet to be utilized optimally, so failed to partially poverty as well as fishermen and fish farmers are still quite high. The Government of East Java province to prioritize development in fisheries and marine very reasonable considering the condition of natural resources in East Java, especially power support fisheries and marine businesses. Fisheries business development efforts in the outline is the effort of catching fish in the sea and diperairan General, aquaculture venture in marine, freshwater and brackish and salt production (Renstra DPK East Java, 2015).

Pacitan waters bordering Indian Ocean and has rich coral clusters which are useful as a place of refuge, migratory and breeding fish. This makes the waters of pacitan became the fishing ground is good. The circumstances of the capture area is influenced by a variety of factors, among others, temperature and salinity. The basic conditions of the beach are sandy and weary, tinted crystal clear coastal water. The flow on the South coast of Java is known as the southern Equatorial current throughout the year moved towards the West. 
Marine fishery resources sustainable potential of Pacitan Regency of 34,483 tonnes per year with this type of fishery resources consist of (1) Fisheries demersal resources, namely: fish largehead hairtail, Grouper, snapper, bawal, next door, Bittern, lobster shrimp, etc; (2) Large pelagic fishery resources, namely: tuna, skipjack tuna, Tunny, tengiri, marlin fishing pelagic resources. The small types are trevally, kites, etc.

Fisheries sector development in Indonesia is currently characterized by the absence of a functional relationship between levels and businessmen. Principals of marketing (downstream sector) tend to be self-serving and exploitative. Fisheries network just tied up and is coordinated by market mechanisms. There are three main problems on the side of the fishing market, namely (1) the low diversification of commodities either raw material or the processed material; (2) low level of mastery against the market caused by the lack of intelejensi, strategies and market promotion; (3) the market distortions that cause is not operation mechanisms of the market and push up the cost of production. Distortion of the market also resulted in commodity prices under the price correctly (under value), margin production margin is much smaller than the market trend so people just trying to just trade in the sector.

The business competition getting tougher as the impact of the establishment of the era of free trade have been shifting business paradigm of the Comparative Advantage move to a Competitive Advantage, forcing business/companies choose the right strategy. The intended strategy is where the company is located in a strategic position and be able to adapt to a constantly changing environment. This is generally a goal the establishment of a business entity.

Value chain management is all activities performed in transforming raw materials into products that are sold and consumed value chain Analysis conducted to evaluate all activities and stakeholders as well as something to do in the supply chain, with the aim of help to mediate inefficiencies such as variability, reducing vulnerability and enhancing capacity to adapt to change (Vermulen et al, 2008). Based on the description above, it needs to do research on the value chain analysis regarding processed tuna in Pacitan. Then be gained of how value chain improvement strategies that can give you the advantage of better for the perpetrator-perpetrators in processing tuna in Pacitan.

The goals of the research are as follows: (1) to analyze the mapping (mapping) the value chain processing tuna in Pacitan, East Java; (2) to analyze Critical Success Factor (CSF) in the value chain of processing tuna in Pacitan, East Java; and (3) to analyze the strategies of improvement and increase in value chains conducted by the processing of tuna in Pacitan Regency, East Java.

\section{RESEARCH METHODS}

This research is done in district of Pacitan, Pacitan Regency, East Java. Site selection based on the sampling method of deliberately (purposive sampling method) with the consideration that Pacitan is one area that the tuna-producing potential in East Java. The research was carried out in February-March 2018.

Sampling technique used is non-probalitity sampling with snowball sampling. Samples as key informants was the tuna processed agro-industries manufactures tuna tofu, then continues to the other principals involved in the value chain of processing tuna in Pacitan. The samples used in the study of consumer ad 50 people and 20 workers involved in UD Eza and UD Son of the Ocean.

Methods of analysis used in this study there are 5 stages: first, mapping the value chain analysis to know the mapping of all parties involved, identify the perpetrators and the condition of the product value chain processed tuna. Second, the analysis of Critical Succes Factor (CSF) to see the influence of the successes and failures in attempting to agro-industries processing tuna fish. The third, analysis of governance (governance) to find out the information regulations/rules in a system of coordination and control that exists within the value chain. Fourth, cost analysis and margin to see the share price of the end product and find out the price difference that exists on every performer in the value chain. Fifth, the analysis of the determination of the value chain improvement strategies by conducting benchmarking with competitors, and improvement of the value chain.

\section{RESULTS AND DISCUSSION \\ Mapping Analysis of Value Chain \\ 1. Mapping Actors and Activities of Value Vhain}




\section{A. Mapping of Value Chain Actors}

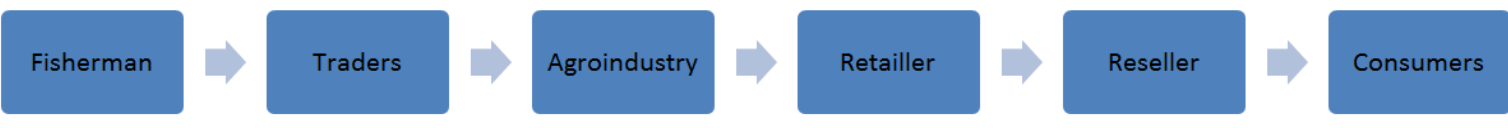

Figure 1. Mapping the offender processed value chain tofu tuna

Source: Primary Processed Data (2018)

\section{Fishermen}

The fisherman is the party that supplied tuna to merchants and processors. The fulfillment of the processed raw material stock tuna tofu is done by a system of subscription and there are no contractual.

\section{Agroindustri}

Identification of the activities of the value chain in agroindustries purposed to know the activities conducted in the produce of processed tuna tofu start from getting obtaining raw materials, supplementary materials, management, processing, packaging, marketing and sales.

\section{Retailer/reseller}

The number of processed tuna tofu retailer at UD. Eza Mandiri there are 2 independent retailer in Pacitan and 8 resellers in outsite of Pacitan.. Whereas on UD. Putra Samudra there are 2 retailer that 1 in district of Pacitan, and 1 in Punung and, 6 reseller in Pacitan, and outsite of Pacitan.

\section{Consumer}

Consumer-targeted market segments are all among the Traveling and visiting to Pacitan.

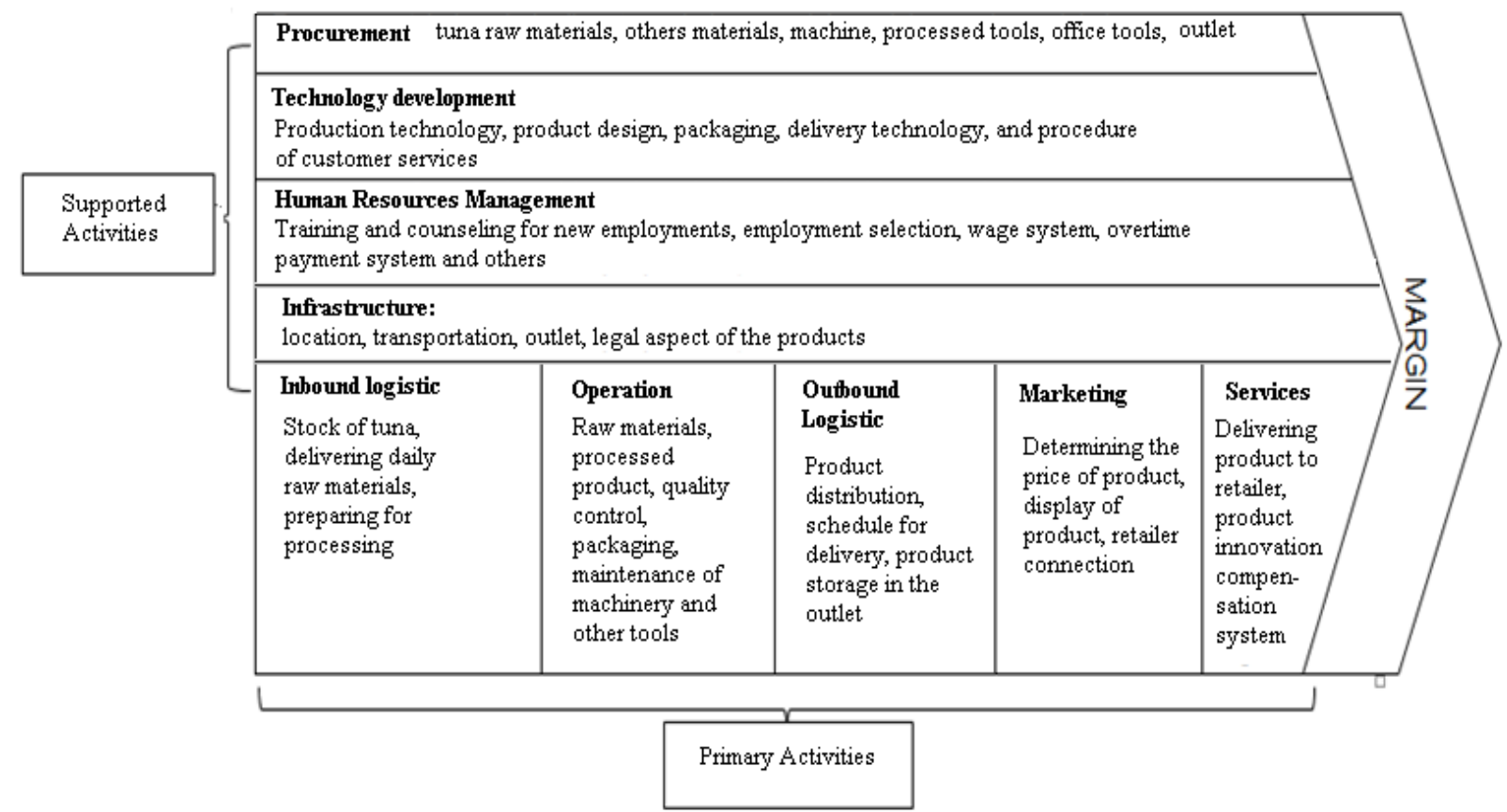

Figure 2. Industrial Agriculture Value Chain Activity Tuna Tofu Source: Primary Processed Data (2018)

\section{B. Activities of Value Chain}

Industrial agriculture value chain activity based on the framework of Porter (1994) contained in Figure 2 that there are below.

\section{The primary Activity}

The activities involved in the physical creation of refined products the tuna tofu, the sales process ranging from distribution to the buyer up to aftersales service.
Inbound Logistics

Logistics into on processed agro-industries tuna tofu starts from the provision of the main raw material, namely tuna and other supplementary material.

\section{Operation}

The operation began with the sorting of raw tuna. Tuna used are grade B and c. after that of raw materials processed in conjunction with additional 
material and other complementary material to be processed products the tuna tofu. Then use a plastic vacuum packing is done to extend store products.

\section{Outbound Logistics}

Aktivitasl on agro-industries began with planning adanaya collection and distribution to the retailer that amount in accordance with the agreement. Distribution of the product to the retailer is done using the car pick-up. The delivery to the demand retailer party depends on the existing stock.

\section{Marketing and sales}

Activities inform and market to the reseller/rerailer, travel agent and consumers through various media both print, electronic, social media. Sales system by sending to the retail stores with the proceeds divided in accordance the agreed treaty. It also opened a reseller outside of Pacitan with mininal limit terms of purchase.

\section{Services}

The activities provide styrofoam packing and shipping process so that products frozen food quality and resilience maintained. Besides innovation processed tuna product diversification, then do return the products that passed the time expires (return).

\section{The Supporting Activity}

Supporting activity is activity that supports the activities of primary and supporting each other by giving inputs purchased, technology development, enterprise infrastructure, and the MSDM (Porter, 1994).

\section{Procurement}

The input purchase activities on agro-industries, namely raw tuna, other supplementary material, machines, equipment for processing into processed products the tuna tofu, stationery and office supplies, as well as in the shop/outlet.
Technology Development

Technology development in agro-industries for processed products the tuna tofu that is stirring dough machines, machines for vacuum packaging, manufacturing design and product packaging, storage technology with a freezer, a vehicle technology used in shipping products, laptop and smartphone technology in the marketing process and logging as well as other services.

Human resource management Human resource management within the company include the recruitment, appointment, training, organizing, and compensation for all employees or engaged in agro-industries.

\section{Corporate Infrastructure}

As for the infrastructure, namely the place of production, the car pick up as means of transportation to distribute raw materials from TPI to the place of processing, and to send tuna tofu is ready to be consumed to retail stores as a place to display and storage product.

\section{The Specific Activities Mapping of Value Chain}

Mapping specific value chain activities are providing an explanation of the production process of starting the provision of inputs up to finished product and marketing. Specific activities include the provision of inputs are infrastructure production, processing/production, and marketing.

\section{Product Flow Mapping}

In tuna processing products, this begins with the process of providing facilities and infrastructure, raw materials, supplementary materials, sorting, filtering, storage of raw materials, production, packaging, distribution, product display, to consumption. In full, it will be explained in Table 1. 


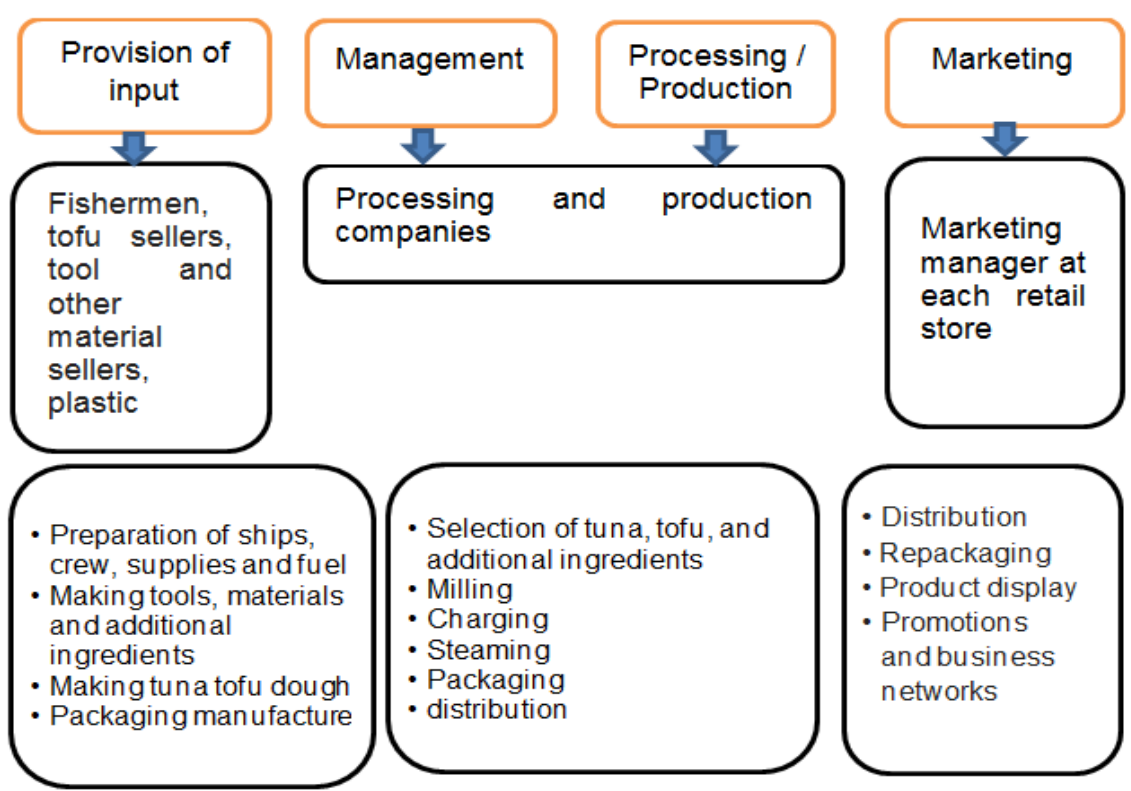

Figure 3. Mapping of Processed Value Chain Specific Activities for Tuna fish Source: Primary Data Processed (2018)

Table 1. Mapping of Processed Tuna Fish Product Flow

\begin{tabular}{|l|l|l|l|}
\hline No & Proccess & Input Form & Output Form \\
\hline 1 & $\begin{array}{l}\text { Fisherman } \\
\text { Preparation }\end{array}$ & $\begin{array}{l}\text { Supplies, fuel, fishing } \\
\text { gear }\end{array}$ & $\begin{array}{l}\text { Various kinds of fish in } \\
\text { the cool box of the ship }\end{array}$ \\
\hline 2 & Go to sea & $\begin{array}{l}\text { Various types of sea } \\
\text { fish }\end{array}$ & $\begin{array}{l}\text { Tuna fish of various } \\
\text { sizes }\end{array}$ \\
\hline 3 & Sorting Fish & $\begin{array}{l}\text { Tuna fish of various } \\
\text { sizes }\end{array}$ & $\begin{array}{l}\text { Tuna fish of a certain } \\
\text { size }\end{array}$ \\
\hline 4 & Filtering & $\begin{array}{l}\text { Tuna intact with head, } \\
\text { tail and fins }\end{array}$ & Fillet tuna meat \\
\hline 5 & $\begin{array}{l}\text { Raw } \\
\text { Storage }\end{array}$ & $\begin{array}{l}\text { Fillet tuna meat tuna and } \\
\text { processing }\end{array}$ & $\begin{array}{l}\text { Fillet tuna meat in a } \\
\text { plastic bag }\end{array}$ \\
\hline 6 & Steaming & Tuna tofu \\
\hline 8 & Draining & Raw tofu tuna & Cooked tofu tuna \\
\hline 9 & Pengemasan & Dried tofu tuna & $\begin{array}{l}\text { Dried tofu tuna } \\
\text { Tofu tuna in the package }\end{array}$ \\
\hline 10 & $\begin{array}{l}\text { Sorting tofu tuna } \\
\text { packaging }\end{array}$ & $\begin{array}{l}\text { Tofu tuna in various } \\
\text { forms }\end{array}$ & $\begin{array}{l}\text { Tofu tuna in a package } \\
\text { that has been vacuumed } \\
\text { tightly without any } \\
\text { leakage }\end{array}$ \\
\hline 11 & Comsumption & $\begin{array}{l}\text { Tuna tofu in a vacuum } \\
\text { plastic package }\end{array}$ & $\begin{array}{l}\text { Tofu tuna is ready for } \\
\text { consumption }\end{array}$ \\
\hline
\end{tabular}

Source: Primary Data Processed 2018 


\section{Mapping Knowledge and Information Flow}

In order to fulfill consumers 'desires, it requires knowledge and information as wide as possible to produce tuna processed products that suit consumers' tastes and have distinctive characteristics and improve product competitiveness.

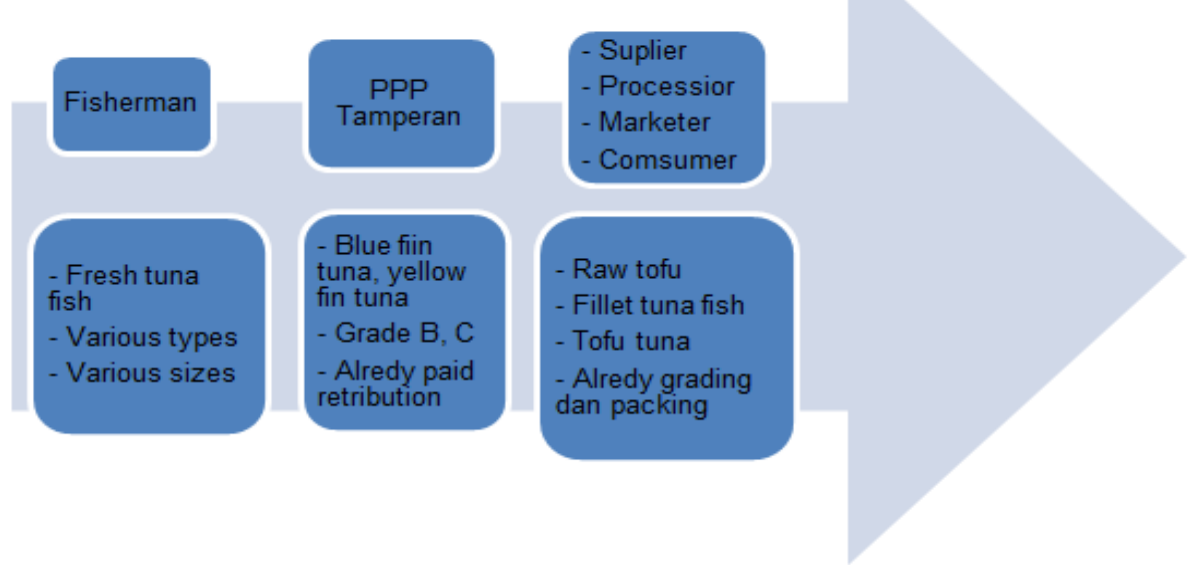

Figure 4. Mapping of Processed Value Chain Knowledge of Tuna Fish Source: Primary Data Processed (2018)

Fulfillment of these needs and desires is done by providing knowledge of tuna fish market needs to fishermen by producers / processing of tuna fish. Standardization, certification, sorting and grading are important things in the processing of tuna by proccesors in the value chain, so it is expected to understand the needs of tuna fish that are desired.

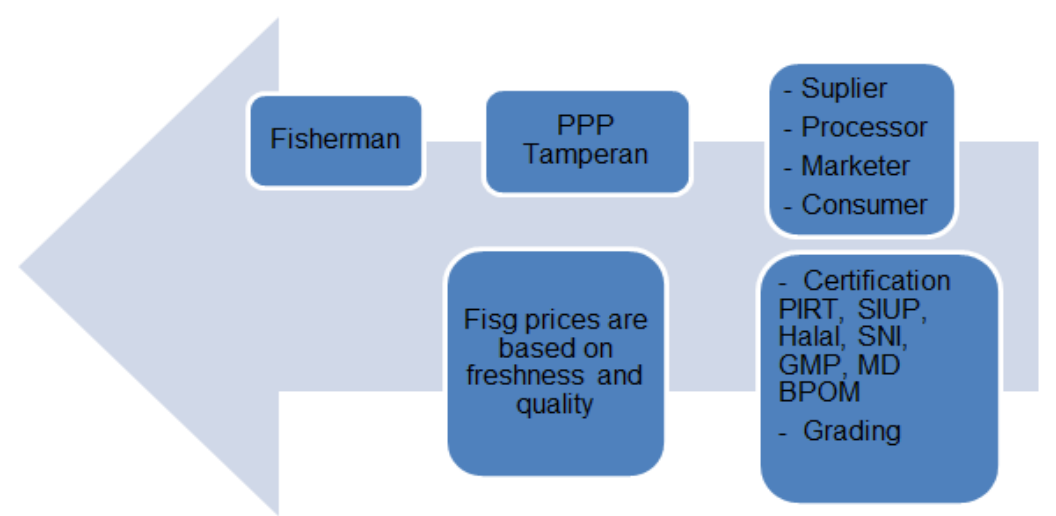

Figure 5. Mapping the Process of Processed Value Value Chain of Tuna Fish Source: Primary Data Processed (2018)

For information in the value chain of tuna fish processing depends on demand, market prices, as well as seeing the quality and price of national tuna fish. Standardization of certain tuna fish processing that underlies the price of tuna is expensive according to a particular target or market segment. In this process the price of tuna fish depends on the shape, freshness, weight and season of the fish.

\section{Volume Mapping}

In Figure 6 showed that fishermen through PPP Tamperan Pacitan as a loading and unloading place distributing fresh tuna to the SMEs 
processing tuna fish by $40 \%$ and to the collecting traders, namely IFA Jaya by $60 \%$. Then SMEs who use tuna to make tuna processed fish products are ready and ready to be distributed to retailers by $80 \%$ and $20 \%$ distributed to resellers. For tuna fish taken by IFA Jaya collectors and then distributed to the ATI Company (Aneka Tuna Indonesia) by $100 \%$.

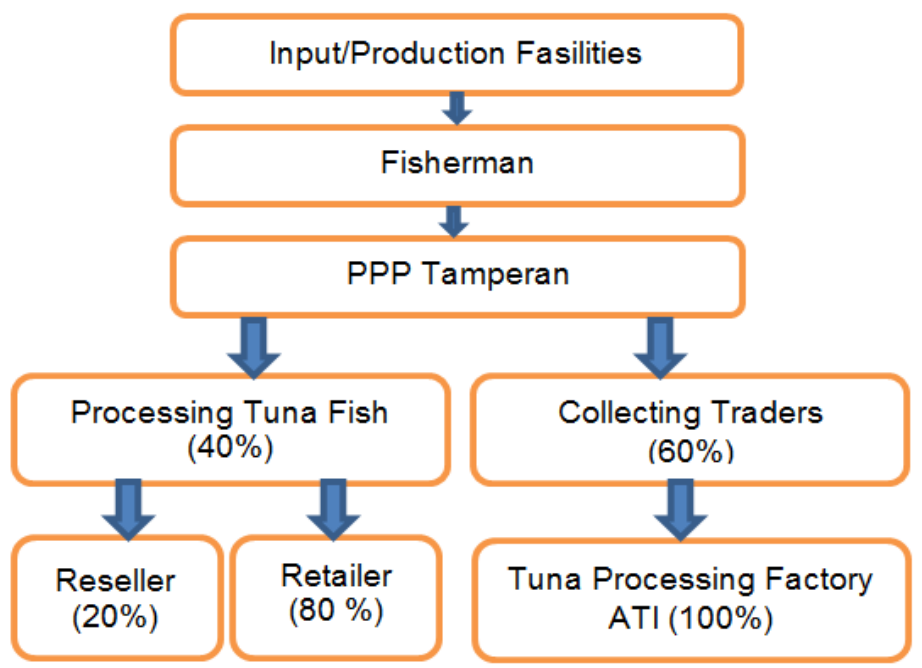

Figure 6. Mapping of Processed Tuna Fish Volumes

Source: Primary Data Processed (2018)

\section{Value Mapping}

The indicator of value mapping is the price of each product in each proccesor. The price increase of each process carried out by the proccesors in the tuna processed value chain can be seen in the table below.

Table 2. Mapping the Value of Processed Tuna Fish Products

\begin{tabular}{|c|c|c|c|c|c|}
\hline \multirow{2}{*}{$\begin{array}{c}\text { Value per } 1 \\
\text { kg }\end{array}$} & Fisherman & Traders & Processor & Retailer & Reseller \\
\hline & $\mathrm{Rp} 17.000$ & Rp 25.000 & Rp 35.000 & Rp 40.000 & 70.000 \\
\hline Value Added & $\operatorname{Rp} 8$ & $\operatorname{Rp} 1$ & Rp 15 & $\operatorname{Rp} 30$ & 00 \\
\hline
\end{tabular}

Source: Primary Data Processed (2018)

From the table above, it was found that the highest value added between fishermen and processors is Rp. 28,000, this is obtained by 1 $\mathrm{kg}$ of tuna fish into 8 packs of frozen food with 1 pack weighing 200 grams for Rp. 6,000 so that $8 x$ Rp. $6,000=$ Rp. 48,000. Tofu processed tuna products per 200 grams in the form of frozen food.

\section{Mapping Correlation and Correlation}

There were three types of mapping of the correlation in the value chain of tuna fish processing, namely the first established market relations (spot market relations) between fishermen and certain tengkulang, the transaction is directly in an agreed place.

Second was the relationship that continues to exist between fishermen and certain middlemen who have become subscriptions without certain agreements. While the three horizontal integration correlation between fishermen and PPP Tamperan, where fishermen must record and provide fees to PPP Tamperan per kilogram of fish. The following is a scheme of correlation and linkages between proccesors in the value chain processed tuna in Pacitan which is presented in Figure 7. 


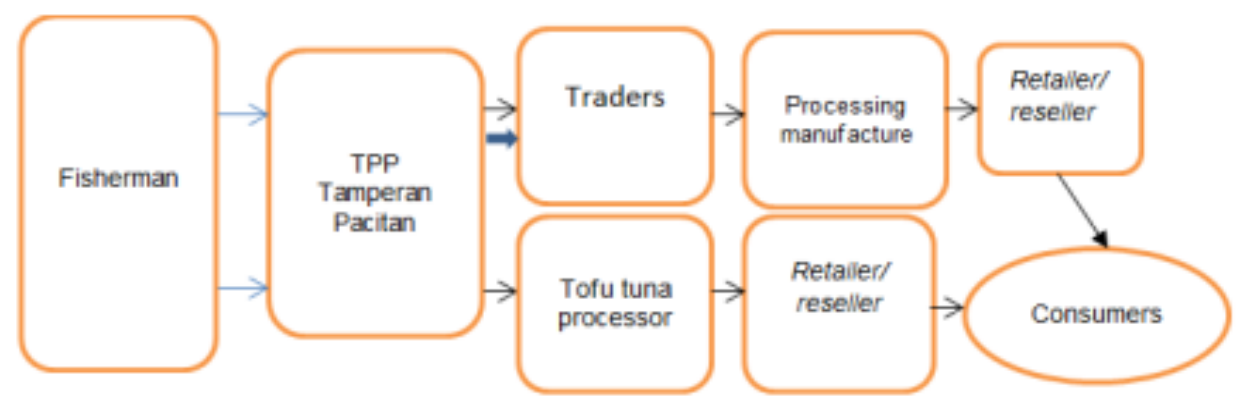

$$
\begin{aligned}
& \Rightarrow=\text { Spot Market Relation } \\
& \rightarrow=\text { Continues Relation } \\
& \rightarrow=\text { Horizontal Integration Relation }
\end{aligned}
$$

Figure 7. Mapping of Correlation and Linkages of Processed Value Chain of Tuna Source: Primary Data Processed (2018)

\section{Marketing Margin}

Marketing Margin is the price difference that occurs between proccesors in the value chain. Its usefulness is to find out the benefits gained by each proccesor in the value chain. The following is a margin calculation table and the price share of each proccesor in the value chain

\begin{tabular}{|c|c|c|c|c|c|c|}
\hline \multirow[b]{2}{*}{ Actors } & \multicolumn{2}{|c|}{ Cost } & \multicolumn{2}{|c|}{ Laba } & \multicolumn{2}{|c|}{ Margin } \\
\hline & $\begin{array}{l}\text { Total } \\
\text { Cost Per } \\
\text { Unit/kg }\end{array}$ & Price & Laba & $\begin{array}{l}\text { Laba Per } \\
\text { Unit (\%) }\end{array}$ & $\begin{array}{l}\text { Margin } \\
\text { Per Unit }\end{array}$ & $\begin{array}{l}\% \quad \text { Retail } \\
\text { Price }\end{array}$ \\
\hline Fisherman & Rp 12.000 & Rp 16.000 & $\operatorname{Rp} 4.000$ & $15,09 \%$ & Rp 16.000 & $32 \%$ \\
\hline Traders & $\operatorname{Rp} 17.000$ & $\operatorname{Rp} 22.000$ & $\operatorname{Rp} 5.000$ & $18,86 \%$ & $\operatorname{Rp} 6.000$ & $12 \%$ \\
\hline Processor & $\operatorname{Rp} 25.000$ & $\operatorname{Rp} 32.500$ & $\operatorname{Rp} 7.500$ & $28,38 \%$ & Rp 10.500 & $21 \%$ \\
\hline Retailer & Rp 35.000 & $\operatorname{Rp} 40.000$ & $\operatorname{Rp} 5.000$ & $18,86 \%$ & $\operatorname{Rp} 7.500$ & $15 \%$ \\
\hline Reseller & $\operatorname{Rp} 45.000$ & $\operatorname{Rp} 50.000$ & $\begin{array}{l}\text { Rp } 5.000 \\
\text { Rp } 26.500\end{array}$ & $18,86 \%$ & $\begin{array}{l}\text { Rp } 10.000 \\
\text { Rp } 50.000\end{array}$ & $\begin{array}{l}20 \% \\
100 \%\end{array}$ \\
\hline
\end{tabular}
can be seen in Table 3 .

Table 3. Marketing Margins of Tuna Fish Processed Value Chain per Unit / kg

Source: Primary Data Processed (2018)

In the table above showed the largest marketing margin obtained by fishermen with a value of $\mathrm{Rp} 16,000$ or $32 \%$ of the retail price and profit of Rp 4,000 per unit / kg. The second largest margin is the processor of Rp. 10,500 or $21 \%$ of the retail price and profit of Rp. 7,500 per unit $/ \mathrm{kg}$. The third biggest margin was the reseller with a value of Rp 10,000 or $18.86 \%$ of the retail price and a profit of Rp 5,000 per unit $/ \mathrm{kg}$. The fourth largest margin is retailers with a

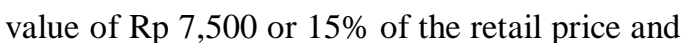

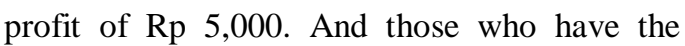
lowest marketing margin are traders with a value of Rp. 6,000 or $12 \%$ of the retail price and a profit of Rp. 5,000 per unit / $\mathrm{kg}$, this is because traders only provide little added value by treating tuna storage with cool boxes / sterofoam boxes. who are given ice. The party who gets the biggest margin is the fisherman who acts as the processor.

\section{Productivity Level}

\section{Wastage Analysis}

The analytical tool used to reduce the level of productivity and find out the loss of resources (inputs) that do not reach the consumer, this was because there were inputs that were sorted due to defects or not fresh, post-harvest processing, distribution and expiration / decay and reject / rejection. The following was the percentage percentage of wastage loss for each proccesor at each stage. 
Table 4. Percentage of Wastage in the Processed Value Chain of Tuna

\begin{tabular}{|l|l|l|l|l|}
\hline No & $\begin{array}{l}\text { Actors of } \\
\text { Value Chain }\end{array}$ & Form & $\begin{array}{l}\text { Wastage } \\
(\%)\end{array}$ & $\mathbf{K g}$ \\
\hline $\mathbf{1}$ & Nelayan & Fresh tuna fish & 15 & 100 \\
\hline $\mathbf{2}$ & Pedagang & $\begin{array}{l}\text { Tuna fish in the cool } \\
\text { box }\end{array}$ & 15 & 85 \\
\hline $\mathbf{3}$ & Pengolah & Fillet tuna fish & 30 & 72,3 \\
\hline $\mathbf{4}$ & Retailer & Frozen food tofu tuna & 10 & 65 \\
\hline $\mathbf{5}$ & Reseller & Frozen food tofu tuna & 10 & 58,5 \\
\hline
\end{tabular}

Source: Primary Data Processed (2018)

According to Table 4 showed that the biggest wastage of processing is $30 \%$, because there is a sorting of tuna of a certain size, then the fillet process separates the head, fin, thorn and meat. Thorn heads and dirt are removed, while the meat is taken to be processed. The fishermen have a wastage value of $15 \%$, this is due to the sorting process carried out by fishermen when they sell fish to traders and processors who ask for the quality of certain fish. Traders have a wastage value of $15 \%$, this is because there is a sorting process carried out by traders and then sold to processors with certain fish demand as well. At the reseller / retailer the wastage value is $10 \%$, because there is a vacuum plastic that is leaky / hollow, expired. Therefore, it is necessary to guard and improve on all the processes that occur in this tuna processed fish chain so that the wastage value gets smaller and makes this value chain more efficient.

\section{Analysis of Production Capacity Indicators}

The analytical tool used to see the level of productivity consists of cycle time analysis and throughput analysis. Cycle time analysis is an analysis that compares costs with time, and compares profits with the time needed for each proccesor in the tuna value processed chain to meet consumer demand. Figure 8 showed the time needed in the process of marketing / distributing tuna processed products from fishermen to consumers.

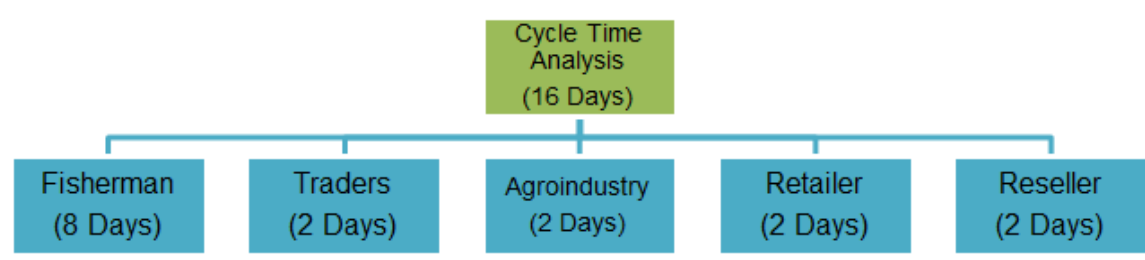

Figure 8. Cycle Time Analysis Processed Tuna Fish

Source: Promer Data Processed (2018)

According to the picture above showed that 16 days is the time needed in the process that is in the value chain processed tuna fish. The first stage fishermen went to sea for 8 days with supplies, then after anchoring in PPP Tamperan fish entered the data collection and retribution. After that the fish is bought by the merchant, it takes 2 days to process the fish by entering it in the cool box and giving it ice so that the shelf life is longer. Then the fish is purchased by the processor, in the hands of the processor it usually takes 2 days for sorting and filtering, and production until packaging.
Furthermore, it takes 2 days for fish processing to be distributed to retailers and then distributed to the reseller within 2 days until the product reaches the consumers' hands.

Then the analysis was done by comparing the results between each proccesor in the value chain. This is to find out which proccesors have the most efficient costs delivered by other proccesors. Detail of the cost per kilogram per time required by each proccesor in the value chain of tuna processed fish is presented in Table 5. 
Table 5. Average Cost/Kg/day in Each Proccesor Processed Tuna Fish

\begin{tabular}{|l|l|l|l|l|}
\hline No & Value Chain Actors & $\begin{array}{l}\text { Cost } \\
\text { (Rp/Kg) }\end{array}$ & $\begin{array}{l}\text { Time } \\
\text { (hari) }\end{array}$ & $\begin{array}{l}\text { C/T } \\
\text { Rp/Kg/Day }\end{array}$ \\
\hline $\mathbf{1}$ & Fisherman & 12.000 & 8 & 1.500 \\
\hline $\mathbf{2}$ & Traders & 17.000 & 2 & 8.500 \\
\hline $\mathbf{3}$ & Processor & 25.000 & 2 & 12.500 \\
\hline $\mathbf{4}$ & Retailer & 35.000 & 2 & 17.500 \\
\hline $\mathbf{5}$ & Reseller & 45.000 & 2 & 22.500 \\
\hline
\end{tabular}

Source: Primary Data Processed (2018)

From the table above it can be shown that the highest cost is retailers because it needs a large place for product display, it needs a freezer to store products with large electrical power and other operational needs in retail stores, so that the required costs are Rp. 22,500 / $\mathrm{kg} /$ day. And it takes a relatively short time of 2 days to store and ship from retailers to resellers. While those who issue the lowest cost are fishermen, which is Rp 1,500 / $\mathrm{kg} /$ day, because the management process is carried out only catching and then put in the cool box in the ship, after arriving at PPP Tamperan directly sold to traders / processors, which takes 8 days to go to sea. So that it can be concluded with the following formula.

$\mathrm{C} / \mathrm{T}$ Fisherman $<\mathrm{C} / \mathrm{T}$ Trader $<\mathrm{C} / \mathrm{T}$ Processing $<\mathrm{C} / \mathrm{T}$ Retailler $<\mathrm{C} / \mathrm{T}$ Reseller Information:

$$
\begin{aligned}
& \mathrm{C}=\text { Cost } / \text { cost }(\mathrm{Rp} / \mathrm{kg}) \\
& \mathrm{T}=\text { time of activity (days) } \\
& <=\text { smaller than }
\end{aligned}
$$

\section{CSF Analysis (Critical Succes Factor)}

According to Kaplinsky and Morris (2000), the analysis of critical success factors is an analytical tool to formulate what critical factors need to be considered by tuna processed agroindustry in accordance with the wishes of the consumer or the final market so that it is expected to increase the competitive advantage of the product. Besides that, it is also to find out which priority and variable factors must be corrected, so that business activities will reach the desired target. CSF indicators are presented in Table 6.

\section{Comparison of the Level of Interest of Agro- Industry with Consumers}

According to the previous analysis, it showed that the critical factor (CSF) influences the consumer's decision to purchase tuna processed products. In addition, these variables are indicators of the level of importance of agroindustry and consumers in purchasing tuna processed fish. These variables are color, aroma, taste, size, price, packaging, stock, quality, innovation, expiration date, and location. Based on questionnaire data; then, calculating the value of each critical factor (CSF) by looking at the level of importance. Following are the results calculation of the CSF values agroindustries and consumers presented in Table 7.

Based on the table, it is known that the most important factor according to agroindustry is taste, quality, price. Taste and quality factors get the highest value of 6.70 and 6.64 because the agroindustry wants tuna processed products not defective, and can last a long time, with good taste. So that it can attract consumers to buy and consume. The price factor is also important with a value of 6.41 because the determination of prices will affect consumers also in the decision to buy and consume processed products with tuna. Prices must be competitive in accordance with the production and marketing costs that have been incurred. The scent factor gets the lowest value because tuna processed tends to have a slightly fishy aroma where it is natural, but not too problematic for agro-industry because the product is in the form of frozen food. 
Table 6. Critical Success Factor (CSF) Processed Tuna Fish Agroindustry

\begin{tabular}{|c|c|c|c|}
\hline No & Variabel & Definition & Indicator \\
\hline 1 & Colour & $\begin{array}{l}\text { The color that appears on } \\
\text { tuna processing }\end{array}$ & $\begin{array}{l}\text { The color is bright and not } \\
\text { cloudy }\end{array}$ \\
\hline 2 & Aroma & $\begin{array}{l}\text { The scent is the smell that } \\
\text { is present in tuna } \\
\text { processing after the } \\
\text { packaging process }\end{array}$ & $\begin{array}{l}\text { Does not smell fishy and } \\
\text { rancid }\end{array}$ \\
\hline 3 & Taste & $\begin{array}{l}\text { Taste is a taste that shows } \\
\text { good taste }\end{array}$ & $\begin{array}{l}\text { Feels good, not rancid and } \\
\text { still fresh }\end{array}$ \\
\hline 4 & Size & $\begin{array}{l}\text { The size of processed } \\
\text { tuna products after being } \\
\text { packed }\end{array}$ & $\begin{array}{l}\text { The size is according to the } \\
\text { standard in } 1 \text { package } \\
\text { containing } 10 \text { pices }\end{array}$ \\
\hline 5 & Price & $\begin{array}{l}\text { The value of products that } \\
\text { consumers are willing to } \\
\text { pay is in rupiah }\end{array}$ & $\begin{array}{l}\text { Prices must be above the } \\
\text { cost of production and } \\
\text { marketing }\end{array}$ \\
\hline 6 & Packaging & $\begin{array}{l}\text { Standards for packaging } \\
\text { products that are attractive } \\
\text { and safe for consumers in } \\
\text { the process of storing } \\
\text { frozen food }\end{array}$ & $\begin{array}{l}\text { Packaging size is in } \\
\text { accordance with the } \\
\text { provisions, does not leak, } \\
\text { uses special frozen food } \\
\text { plastic, and displays the } \\
\text { product clearly }\end{array}$ \\
\hline 7 & Stock & $\begin{array}{l}\text { Availability of processed } \\
\text { tuna }\end{array}$ & $\begin{array}{l}\text { Customer needs are met } \\
\text { and there is always stock in } \\
\text { the freezer storage }\end{array}$ \\
\hline 8 & Quality & $\begin{array}{l}\text { Healthy product quality, } \\
\text { safe for consumption with } \\
\text { various certifications }\end{array}$ & $\begin{array}{l}\text { There are quality standards } \\
\text { from BPOM, Dinkes, MUI } \\
\text { halal certification, } \\
\text { Disperindag (P-IRT) }\end{array}$ \\
\hline 9 & Tnnovation & $\begin{array}{l}\text { Development and renewal } \\
\text { of products that are } \\
\text { differentfrom the previous } \\
\text { ones }\end{array}$ & 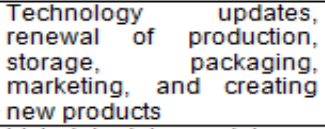 \\
\hline 10 & Expired date & $\begin{array}{l}\text { Date limit that shows how } \\
\text { long the product may be } \\
\text { consumed }\end{array}$ & $\begin{array}{l}\text { Listed kadalursa date on } \\
\text { product packaging and } \\
\text { storage method }-18^{\circ} \mathrm{C}\end{array}$ \\
\hline 11 & Location & $\begin{array}{l}\text { The place where retail } \\
\text { stores sell products }\end{array}$ & $\begin{array}{l}\text { Store location near tourist } \\
\text { area and located on a side } \\
\text { street }\end{array}$ \\
\hline
\end{tabular}

Source: Primary Data Processed, 2018

Table 7. Critical Success Factor Value (CSF)

\begin{tabular}{|c|l|l|l|l|}
\hline \multirow{2}{*}{ No } & \multirow{2}{*}{ Variabel CSF } & \multicolumn{2}{|c|}{ Perceptions } & \multirow{2}{*}{ Values gap } \\
\cline { 3 - 4 } & & Agroindustry & Consumers & \\
\hline 1 & Colour & 5,48 & 5,61 & 0,13 \\
\hline 2 & Aroma & 5,37 & 5,48 & 0,11 \\
\hline 3 & Taste & 6,70 & 6,74 & 0,04 \\
\hline 4 & Size & 5,54 & 5,59 & 0,05 \\
\hline 5 & Price & 6,41 & 6,23 & 0,18 \\
\hline 6 & Packaging & 5,47 & 5,53 & 0,06 \\
\hline 7 & Stock & 5,22 & 5,71 & 0,49 \\
\hline 8 & Quality & 6,64 & 6,71 & 0,07 \\
\hline 9 & Innovation & 5,31 & 5,86 & 0,55 \\
\hline 10 & Expired date & 5,34 & 6,57 & 0,73 \\
\hline 11 & Location & 5,20 & 5,37 & 0,17 \\
\hline
\end{tabular}

Source: Processed Primary Data, 2018

The factor most considered by consumers was taste, quality packaging, expiration date. The highest factor is taste with a value of 6.74 because the taste is the most sought after and is a characteristic of a product that is processed tuna. The taste that is expected by consumers is delicious, tasty, and the texture when it's fried crispy outside, and soft inside. Quality is also an important factor in the decision of consumers to buy processed tuna products. Consumers want fresh, clean, non-defective, long-lasting tuna fish processing, new and have various certifications that guarantee product quality. Furthermore, the factor of expiration date is also important, because by stating the expiration date the consumer can find out the final product limit can be consumed, so it will not harm consumers. While the lowest factor for consumers is the location, because the location is close to the tourist area in Pacitan making it easier for consumers to obtain tuna processed products. 


\section{Improve Strategy of the Value Chain Tuna Fish Processed \\ Benchmarking Analysis}

Benchmarking analysis was used to measure the performance of tuna processing business with competing businesses that are considered superior. In this case the indicator that is a competitor is a more advanced tuna processing business. The indicator is the ability of processors to meet the critical factors that influence the final consumer purchasing decisions. The indicators are price, stock packaging, product sales, quality, innovation, completeness of information, location and marketing with various media.

Table 8. Benchmarking of Tuna Processed Entrepreneurs (Tuna Tofu)

\begin{tabular}{|l|l|l|l|}
\hline No & Indicators & UD. Eza Mandiri & UD. Putra Samudra \\
\hline 1 & Fish Type & Grade B and C tuna & Grade B and C tuna \\
\hline 2 & Taste & $\begin{array}{l}\text { Tasty, savory, crunchy } \\
\text { beyond the inside, not } \\
\text { fishy }\end{array}$ & Tasty, savory, but fishy \\
\hline 3 & Price & IDR 7.500/ 200 grams & IDR 8.000 / 200 grams \\
\hline 4 & Packaging & $\begin{array}{l}\text { vacuum sealed foil } \\
\text { packing, the color is less } \\
\text { attractive }\end{array}$ & $\begin{array}{l}\text { Vacum sealed foil } \\
\text { packing, attractive color }\end{array}$ \\
\hline 5 & Stock & $\begin{array}{l}\text { There are } 8 \text { large } \\
\text { frezzers }\end{array}$ & $\begin{array}{l}\text { There are 10 large } \\
\text { frezzers }\end{array}$ \\
\hline 6 & Quality & $\begin{array}{l}\text { always new, the color of } \\
\text { the product is rather dark }\end{array}$ & $\begin{array}{l}\text { Always new, the color of } \\
\text { the product is cleaner }\end{array}$ \\
\hline 7 & Product innovation & Many kinds of & Many kinds of \\
\hline 8 & Certification & Halal, BPOM & $\begin{array}{l}\text { Halal, BPOM does not } \\
\text { yet exist }\end{array}$ \\
\hline 9 & Store location & Quite strategic & Strategic \\
\hline 10 & Social media & Available & There is \\
\hline 11 & Consumer & Various circles & Various circles \\
\hline 12 & $\begin{array}{l}\text { Form of } \\
\text { cooperation }\end{array}$ & $\begin{array}{l}\text { With the Pacitan } \\
\text { Regency government }\end{array}$ & $\begin{array}{l}\text { With the Tourism } \\
\text { Association in East } \\
\text { Java, Central Java, and } \\
\text { with PO tourism buses }\end{array}$ \\
\hline
\end{tabular}

Source: Processed Primary Data, 2018

According to the table above there are 12 indicators in the benchmark of processed tuna products obtained various advantages and disadvantages of each UD as follows. First UD. Eza Mandiri, has the advantage of Halal certification and BPOM which is declared feasible and safe for consumption complete with expiration dates and population weight per 200 gram pack. UD. Eza Mandiri is one of the pioneers of tuna tofu processing in Pacitan. Know the tunes aren't fishy. And the downside is that the location is less strategic and there is no form of cooperation with the tourism associations of East Java and Central Java and there is no collaboration with PO tourism buses, so that the public is less widely known as competitors. Stocks are less than more than competitors. Smaller retail stores are not like competitors. No other business has been developed such as the existence of restaurants in retail stores.
The Benefits of processed products UD Putra Samudra are an attractive product packaging color with attractive colors. There is cooperation with the Tourism Association in East Java and Central Java, as well as collaboration with PO tourism buses, so that sales run continuously and smoothly, and products are more widely known in various regions of East Java and Central Java with word of mouth testimonies. In addition, it also has another business, namely a restaurant with a menu of processed fish products that are located in one location with retail stores in the district. Punung. The location is also more strategic for tourism bus parking in the spacious retail store yard because it is close to goa gong tours, klayar beach, buyutan beach, banyu tibo beach. Tourists travel in tourist areas while bus crews rest in the rest area provided by UD. Eza Mandiri. As for the disadvantages, the price is more expensive, processed tofu tuna is rather fishy, so it needs $\mathrm{R}$ and $\mathrm{D}$ to make those that 
don't smell fishy. There is no BPOM certification, which is reportedly still being managed and has not yet come out of the central BPOM. The weight in the package has not been listed. So that it is expected that repairs can take care of BPOM certification, and include the weight of the product in the package.

\section{Governance Analysis}

This analysis was used to understand the regulations, policies and regulations that exist in a value chain. Some policies from relevant stakeholders are:

1. The Pacitan Regency Marine and Fisheries Service

a. Provision of business capital assistance and tuna processing equipment

b. Provision of good and correct training and processing socialization

c. Training on certain certified tuna fish processing (BPOM, P-IRT, halal, KAN, etc.)

d. Periodic coaching of tuna, both SMEs and SMEs

e. Provision of marketing network for tuna processing business

2. Industry and Trade Office of Pacitan Regency:

a. Increased added value of tuna processed products and prepare SNI for tuna processed products; regular data collection for processed tuna products

b. Processing training is ISO 9001: 2008 standard and institutional and partnership development

\section{Upgrading Analysis}

Improvements that can be made are improvements in product quality, functional and new value chains.

1. Process Upgrading

The process that can be done by tuna fish processors is:

a. Using a milling machine and a mixing machine with a larger grinding capacity

b. Add freezer for raw material storage

c. Add a vacuum machine to speed up the packaging process

2. Product Upgrading

The improvements that can be made are: a. Innovate and diversify tuna processed products

b. List BPOM certification, halal products (MUI), KAN, SIUP, permits from the Fisheries Service, Disperindag, Investment Services.

c. Maintaining the stock of frozen food processed products so that they are always available both from raw materials and other ingredients

d. Repairing attractive packaging designs and according to frozen food standards

3. Function Upgrading

The improvements that can be made are:

a. Increase the capacity of fish meat milling machines, dough mixing machines and vacuum machines to increase production capacity and capacity, thereby reducing production costs.

b. Weighing the product with a certain weight per package, giving the production date and expiration date on the product wrap, thereby reducing product returns and reducing losses.

4. Chain Upgrading

The improvements that can be made were:

a. Synergizing processors and marketers of tuna fish processing so as to increase product value, effective empowerment of POKLAHSAR so that it can increase the income of fishermen and processors, especially from marketing margins.

b. Adding a new chain that is more effective is by collaborating with travel travel as a stopover for shopping for typical Pacitan souvenirs.

\section{CONCLUSION}

Based on the research conducted, the following conclusions were obtained:

1. The proccesors involved in the value chain of tuna processing are started from fishermen, traders, processors / agroindustry, retailers, resellers and consumers. The cost required for fishermen is Rp. 12,000, the trader is Rp. 17,000, the agro-industry is $\mathrm{Rp}$. 25,000, the retailer is $\mathrm{Rp} .35,000$, the reseller is $\mathrm{Rp}$. 45,000. The party that issues the biggest cost is a reseller with a profit value 
of Rp. 5000. The party that earns the smallest profit of fishermen with a value of Rp. 4,000. Fishermen who are also agroindustry obtained more marketing margins than fishermen who just go to sea.

2. Critical factors according to the agroindustry processors are taste, price and quality. And the critical factor in analyzing consumers is taste, quality and expiration date. The factor that has the highest gap value is the stock of 0.49 innovation factor of 0.55 and the expiration date of 0.73 . Mentoring, training, coaching and downstreaming in the tuna fish processing value chain has an important role in giving consumers preference regarding taste, packaging and better marketing.

3. The strategy for improving the value chain of tuna fish processing is the improvement of the process by increasing the production capacity of management after the sea and the processing process at the time of production, which is useful to reduce production costs. Empower marketing managers to play an active role and improve network marketing. Branding on other products which are also processed tuna fish with national and international standards.

\section{REFERENCES}

Kaplinsky, R., \& Morris, M. 2000. A Handbook For The Value Chain. Sussex: Institute of Development Studies at the University of Sussex.

Porter, Michael E. 1994. Keunggulan bersaing: Menciptakan dan Mempertahankan Kinerja Unggul . Jakarta: Tim Penerjemah Binarupa Aksara.

Renstra Dinas Perikanan dan Kelautan Jawa Timur Tahun 2014-2019, 2015. http://dkp.jatimprov.go.id/wpcontent/uploads/2017/04/RenstraDiskanla-Jatim-2014-2019.pdf. Accessed on 15 May 2017.

Vermeulen, S., J. Woodhill, F. Proctor, and R. Delnoye. 2008. Chain-Wide Learning for Inclusive Agrifood Market Development. A guide to Multi-Stakeholder processes for Linking Small-scale Producers to Modern Market. IIED and CD\&IC. Wageningen University and Research Center. Netherlands. 